\title{
Constructivism, National Identity and Foreign Policy of the Islamic Republic of Iran
}

\author{
Hossein Karimifard \\ PhD Student, Department of International Relation, Science and Research Branch \\ Islamic Azad University, Tehran, Iran \\ E-mail: h.karimifard@yahoo.com
}

Received: August 21, 2011

Accepted: September 12, $2011 \quad$ Published: February 1, 2012

doi:10.5539/ass.v8n2p239

URL: http://dx.doi.org/10.5539/ass.v8n2p239

\begin{abstract}
This essay considers foreign policy of the Islamic Republic of Iran based on elements of national identity. National identity of Iran is a cognitive subject based on mutual understanding of Iran and other countries. National identity of the Islamic Republic of Iran is the conception of this country from itself based on realization and conception of other countries from it. The research hypothesis is as follows: Iran's policy, orientation and treatment of foreign policy have been influenced by the ideas of national identity.
\end{abstract}

Keywords: Constructivism, National identity, Foreign policy, Islamic Republic of Iran

\section{Introduction}

The relevance of national identity and foreign policy did not get noticed for many years because of paradigm dominated by realism in international relations. In the theory section of Morgenthau's book (Politics among Nations) and Kenneth Waltz's books (Man, the State and War) and (Theory of International Politics), the connection of culture and national identity of a country with its foreign policy is clearly denied. Another reason of less attention to this issue was the domination of behaviorism and attention to tangible and measurable phenomena. As a result, the definition of culture and its determination with other phenomena were difficult work. But the identity component found its position in international relations with manifestation of constructivism approach in international field and emphasizing on the immaterial attitudes, ideas and elements.

Thus the realistic analysis of the Islamic Republic of Iran's foreign policy is possible based on the concept of identity and its elements. With understanding the identity of system we will be able to understand conceptual structures which according to it, the government and its agencies classify and make sense the world in its frame. In the logic of constructivism, identity is not pre-given but since it was historical, it is the result of an awareness existence in knowing basic concepts; it is acceptable in the society. In this respect that identity is a constructive act it refers to its resources and roots.

\section{Theoretical framework: structural oriented in international relations}

Original propositions of structural oriented are usually expressed as follows:

A: in the theory of international policy, the primary unit of analysis is governments.

B: the main and basic structures in the system of governments are inter-subjective not material.

C: Government benefits and identity are made by these social structures. (Howard, 2005)

Different and alternative understanding is presented by constructivism about the anarchy and the balance of power, the relationship between identity and benefits, complexity of power,...(Hopf, 1998:175)

\section{Identity in foreign policy analysis}

Identity is a main concept in the current theories of international relations especially in different constructivism and a political action is usually explained by referring to the identity of a country. Benefits are being constructed socially and the benefits of each country depend on its identity; if we do not know who we are, we won't know what our benefits are. Values and norms form identities in the realm of domestic and international politics. 
Identity is given priority by other sources of meaning as "similarity and uniformity of general and fundamental features" or "meaning-making process based on a cultural feature or a continuous vague set of cultural features"... . Identity is a source of meaning and experience for people. There might be some identities for each actor so this issue causes tensions and contradictions. In some cases there is sophistry between identity and role. In comparing with role, Identity is a more powerful semantic reference because it comprises the processes of its making and selfdom. In fact, identity is the organizer of meaning but role is the organizer of actor function. (Costales, 2001:3-22)

Collective identity is usually defined negatively. It means a person is considered Iranian in this respect that he is not Iraqi or Russian and we know ourselves as "we" because we are separate from them. Similarity and uniformity that can be achieved in our identity by resorting to "others", confirm and verify the continual identity. Someone even believes that a threatening neighbor is so essential for domestic peace and if there is not already, it should be made by mutual consent. (Samti, 1997: 6-135)

The first thing that comes to our mind to the issue of identity is the discussion of disability and change, especially identity fluidity has been approved however this fact does not dilute the meaning of identity. Identity is an agent or a topic of change however it is the main agent in change which explains the change with its weakness or power and make it intelligible. Even though the identity is the topic or the area of change, again something remains that is fixed and does not change, and that is the government will which focuses on being different. (Karami, 2005:48)

Against the rational approach in international relations which assumes the actors' identity in international field independently, constructivism insists on the fictional identity of actors. Distinct approach lies in the topic of ontology. Constructivism does not accept rationalist's assumptions of human nature and emphasizes on actors' identities in the social construction.

Since identities form the benefits and acts of actors, understanding them is vital for analysis of foreign policy and international behavior of actors. Identity means relatively constant understanding based on their role of vacancy and others expectations. Thus it is a relationship matter. Identity is made in social interaction and strengthened.

\section{Components of Iran's national identity}

Every government focuses on a mark or specific sign and makes its image to be recognizable from other governments. Thus governments play different roles in the world and there might be different mission for each of them according to its nature; for example the government that emphasizes on its historical duty. The kind of government is specified according to its social groups, interests, values and characteristic. (Headley, 2007: 1-2)

After the Revolution of 1979, cultural concerns were discussed among Iranian scholars. Opinions were expressed about nationality identity of Iranians. Supporters of the Islamic Republic of Iran propounded "Shiite Islam" as the social identity of Iranian. Whereas Iranian secularists focused that religion lies in language-ethnic heritage. Nationalist intellectuals stressed that language is the source of national identity. Language has essential role in the discourse of Iranian cultural heritage. Some of cultural historians and literary critics believe that Iranian nation is defined with Farsi language. For these scholars Farsi language is the manifesto of thoughts, experience and wishes. Some of authors know Farsi language as the most significant factor of Iranian nationalism. From the perspective of Iranian intellectuals, national identity of Iranian is constructed of three elements of "Pan-Iranism", "Pan-Islamism" and "modernism". In this part each of the components is explained briefly:

\subsection{Pan-Iranism}

In the framework of Pan-Iranism, the major reference of Iran's national identity is Iranian nation and nationality. Nation has an independent value, life and dignity. According to the definition of nation, elements and components of Iran's national identity forming are land or geographical range, population, language, race, religion, shared history, culture and traditions, common political structure and economic relations. Someone knows Iran's unity as an only element and the central focus of Iran and consequently its national identity. On this basis, national identity is in the first place of geographical and political issue and it relates to the way it emerges and survival of Iranian nation and feeling of belonging to it. (Dehghani, 2007: 126)

Iranian philosophy which considers human's identity as a fact, drives from beginning of Iran's civilization and culture. In the eternal struggle of light and darkness world, Zoroastrian culture binds human to come in favor of light and do an endless effort to prevent the domination of darkness and to make a brilliant victory in the fight. Furthermore the right struggle against the wrong is emphasized in the Islam of Iranian (Islam of Shiite). In the 
other word, the culture binds human to fight against darkness and to live in dignity and happiness. (Mojtahedzadeh, 2007: 5-114)

\subsection{Pan-Shiisem}

Against nationalism which forms around nationality, focal and central point of Shiite is based on Iran's national identity, "Islamism". Since the Shiite religion helped Iranian's national identity and clarified national, cultural and religious borders in this way, it manifested itself as a founder of new Iran and reviver of past glory and symbol and independency of this country. Therefore what conducts Iranians' act in foreign and domestic field is the Shiite religion. Therefore in this regard, the political and social weight of scholars is added. It made them as the most obvious symbol of civil society and Shiite clergies stand on the border of the civil society and the political one. (Naghibzadeh, 2003: 5-114)

Although the Shiite religion is almost political, Islam becomes politically active in Iran from the early twentieth century. It found the claim to interfere in politics and to implement Sharia as the law... more political Islam in the twentieth century was in the response to pressures and modernism threats so it was in a defensive position. In fact in all religions whenever modernism threats their religion and old lifestyle, their natural reaction was in the way of intensifying in religious affiliations and returning to religion and its basic principles or as it is called today "fundamentalism". (Bashirieh, 2005: 143)

According to this view, politics in Islam is not merely human and secular and apart from religion, but it is monotheism which is following the unity of the Muslim world. (Ranjbar, 2007: 70) Thus the Shiite religion becomes the strongest element in Iranian national culture and maintains its authenticity and consistency up to now. An attempt in twentieth century took to integrate Iranian and Islamic culture and to juxtapose elements of Iranian culture with Islamic ones. Its agents were the secular, political and religious elites. Another factor which weakened Iranian and Shiite culture was new elements of cultural modernity.

\subsection{Modernism}

The second most important cultural collapse was the entry of modernity to Iran. The deep impact of collision with the West led to the creation of new cultural codes which challenged to many elements of traditional culture. The challenge is the major issue in the last two hundred years and the main focus of political and social conflict. Meanwhile Iran has the joint issue with many third world countries because Napoleon's campaign to Egypt in 1798 is seen as starting point of European domination around the world. (Naghibzadeh, 2002: 116)

Most people who have studied about Iran's political culture believe that Iranian Constitutional Revolution was Iranian political awaking and entering to a new realm of politic, government and law. (Kazemi, 2003: 8-146)

Reza Shah and Mohammad Reza Shah era are considered a very important period in the history of modernity and significant development took place in this era. First it was necessary that a large number of people be educated and trained to eliminate the necessities of a new army, and to promote industrial development, new and related services such as banking. In the Mohammad Reza Shah era (second Pahlavi), the most significant political and cultural element was modernism. Creators of Pahlavi's post-dialogue attempted to achieve the latent power of Western nationalism via new identity from historical texts and signs. Dominance of positivism and new method of positivist had led Iranian elites to this conclusion that west is the destination of non-western societies including Iran. Therefore in learning knowledge and in the theory and practice field via positivist way, the West was the symbol of some values such as progress, freedom and secularism. (Tajik, 2004: 34-38)

In short; Iranian identity has always been changed for historical, political and social reasons. The country has tended to be in the center of civilization, while it was on the fringes of civilization, in many times and periods. The dual and paradoxical position caused a multifaceted identity for Iranians. Iranian multifaceted identity means its complexity and development.

\section{Identity construct of Iran's Islamic Revolution: Islamic dominated discourse on Iranian and modernism dominated on tradition}

The contrast between religion and nationality in Iran leads political processes of conflict, power struggle and competition to gain influence and it did not manifest in inherent contrast between religion and nationality in Iran. Since each of the competing forces considered one of the elements of Iranian national and spiritual identity as a basis of legitimacy, their competition and struggle over power and politics were drawn to the conflict between religion and nationality. The contrast intensified when nationalist political groups such as National Front and National Democratic Front opposed religious politics of Islamic Republic in political, legal and social fields. Political opposition of nationalist forces was considered an anti-Islamic movement and an opposition to the Divine laws by opponent elites who controlled government offices. The peak of this political conflict was 
nationalist objection against blood ransom Act. As a result of the issue Ayatollah Khomeini declaimed that nationalist is against Islamic government. He announced the apostasy verdict for national Front. (Ahmadi, 2004:83)

With the victory of Islamic Revolution, discourse of ideological traditionalism supported social discipline, unity and cultural equalization and intellectual and social coordination in the form of its overall identity with attempt in the revival way of Islamic and Shiite traditions against modern world tendency, national and non-religious identities. Discourse of ideological traditionalism attempted to renovate and to define human and society in an anti-liberal approach based on their traditional and religious values. Hence the continuation of theoretical conflict with the West or anti-west is necessary for continuing the identity build on the ideology of Islamic Revolution. (Bashirieh, 2003: 7- 126)

These unbalanced approaches to the constituent elements of Iranian identity and excessive focus on religion were harmful for Iranian nation and their historical, cultural and political heritage. The consequences can be briefly noted as follows:

- Fueling the crisis of identity among Iranians.

- Development of trans-national and infra-national

- Putting Iran in front of challenges and foreign enemies in regional and international level.

- Being prepared the background for distorting national history of Iran.

- Inharmonious emphasis on religion which led damages to the religion.

The factors have been effective on foreign policy of the Islamic Republic. Shireen Hunter in her book "Islam and the West" believes: four factors help instability and fluctuation in the foreign policy of the Islamic Revolution:

1). Dominance of new traditionalism over Iran's political structure and its determining role in foreign policy.

2). Ideological and non-realistic evaluation from his own strength.

3). Reaction of other countries in international agencies against revolutionary defiance of the Islamic Republic of Iran.

4). Revising in Iran's ideological perspective. (Hunter, 2001: 220-230)

In short, lack of conformity in Iran's foreign policy with the world is due to the contrast of traditionalism to the government of Iran and domination of modernism over international relations.

Ideology of the Islamic Revolution was in contrast to America, the West, puppet Arab regimes, Israel and the majority of governments with Western and capitalist tendencies. On the one hand the Islamic Republic of Iran was creating a new order in Iran; on the other hand it was attempting to change the Muslim world and developing countries and to help streams of the third world revolutionary. With new constitution of the Islamic Republic of Iran, the behavioral features became institutionalized and legal in foreign policy of the country. Although Iran's developments affected the region seriously and led political and religious mobilization and many symptoms of rising Islamic movements for political change were found in Muslim countries, the Middle Eastern governments especially in Muslim countries started their counteractions against the waves of the Islamic Revolution. (Sari'olqalam, 2005: 64)

\section{Foreign policy construct of Iran's Islamic Revolution: Prominent of pan- Islamism component (pan-Shi'aism) after Revolution}

In the process of the Islamic revolution, hegemonic discourse formed which lay in Islamic tradition. The revolutionary discourse redefined domestic and foreign policy fundamentally and presented different criterions for defining "itself" and "other" in the national and trans-national field. Therefore it challenged world dominant discourse and threatened the order governing relations and international relations. It mobilized various associations against global hegemonic power and entered new variables into the international policy. Thus in the result of discourse of the Islamic Revolution, distinct discourses of foreign policy formed and behavior of Iran's foreign policy also formed in its framework. Pan-Islamism (Shi'aism) and nationalism are the components of Iran's foreign policy. The components of language nationalism are culture and ethnicity. The component of pan-Islamism is global ideology which attempts to export it to other countries. "Defending of all Muslim rights" rises from this ideology. Therefore Iran supports Hamas, Hezbollah and Islamic Jihad groups.

Guardianship of the religious jurists (velayat-e-faqih) rises from the ideology which is opposite of traditional Islam. 
Imam Khomeini considered the interests of Muslim community (umma) and with refusing the nationalism concept slighted many ideas of secular national interests. He also refused the international system based on government-national. He was a supporter of an Islamic world order for human benefit. Islam is for humanity to regulate them under the umbrella of justice. Here again Iranian tradition claims ruling world. Entering to universalism element was seen by Imam Khomeini When he wrote a letter to Gorbachev in January 1988. He questioned the East-West ideological vacuum and supported Islamic values. He wrote that Islam can save all nations. (Ramazani, 2004: 556)

\section{Analyzing Iran's foreign policy according to national identity components}

The Islamic Republic of Iran used Islam to weakened legitimacy of conservative Arabic countries. Iran used Shiite card significantly. Especially it was obvious in wartime. Ayatollah Khomeini also talked about Pure Muhammadi Islam (ISLAM-e-NAAB-e-MUHAMMADi) against American one. In his point of view Islam of some Arabic countries is American Islam.

For more domination, hegemonic Islam fought against opposite ideologies (socialism, nationalism, liberalism, left party, pan-Islamism and regionalism). The process which was both peaceful and violent, led advertises of substitutes for the society after revolution. Hegemonic Islam revealed as one of substitutes in the constitution of the Islamic Republic. Despite the disagreement in some details, it has been accepted in its general by majority. Later, making Islamic government had a profound impact on law, justice and education fields.

To understand Iran's foreign policy, the semantic structures inside Iran should be noted in agencies, official offices and media commentaries. Three important components of independence, justice and residence form the identity of the Islamic Republic. In theory of structural oriented for explaining foreign policy we attempt to communicate among identity, interests and government structures.

Now the most important signs of identity in foreign policy are considered:

\subsection{Radicalism in the field of international relations}

The position of superiority and inferiority in the hierarchy of international system which reminds a Western maker structure and a stranger maker, After revolution made stronger sense to anti-hegemonic identity in foreign policy discourse. Thus revolutionary Iranians' words and deeds were directed to rioting against hierarchy of international system and to denying hierarchy of international system by revolutionary Iranians who are reminiscent of the West negation as a superiority object which was appeared in foreign policy discourses. The irritating object gave meaning to anti-hegemonic discourse identity. The identity redefined anti-structural nature and anti-hierarchical international system. Breaking the structure in the position of international and denying the current situation were in the following of escaping from captivity of revolutionary Iranians. Denying hierarchy of international system and its anti-structural nature led to negate international agencies and organizations in the foreign policy discourses of the Islamic Republic; since the agencies and organizations were reminiscent of West-America for revolutionaries.

\subsection{The support of liberation movements and opposition to the great powers}

Article 154 in the constitution of Iran emphasizes "the Islamic Republic of Iran supports the rightful struggle of oppressed people against their oppressors anywhere in the world while completely refraining from any interference in the internal affairs of other nations." The policy and its related function are perhaps the most revolutionary policy and the action of the Islamic Republic. The policy is in the scope of the world. It is again divided among actors based on their ability level. According to the article of the constitution, the Islamic Republic must be faithful to its beliefs and refrain from cooperating with the centers of power. The policy was applied wildly for the first few years. Iran became the centerpiece of travel of all liberation movement, political movement and opponent of regimes. Iran was also a supporter of the opposing streams of great powers. Perhaps it was the idea of dominant political men that purchasing and transferring of technology do not lead political affiliation; while political relations may create conditions that cause dependency or its extension is conditioned to the acceptance of items and brings political participation for the country. The Islamic Republic of Iran in its international relations has often applied resolution policy of communications; therefore it divided the political, cultural, commercial, oil and economic relations from each other. Thus Article 154 in the constitution is natural and relevant for a revolutionary country or newly one. As time passes, the only applicable case in Iran's foreign policy performance is movement of Palestinian liberation which has very crucial role in Iran's international relations. (Sari'olqalam: 70) 


\subsection{Anti-Americanism}

If the image of "America- West" is psychologized in Iran's foreign policy discourse, one of the images which can be evaluated in the cultural-discursive area is that "America-West" is "the object of horror". The feeling of fear and insecurity toward a strange object, "America-West", for revolutionary subjects is considered as a genuine subject in socio-political system of Iran before the Revolution. In fact, the widespread fear and insecurity were a part of psychological and social features of its time. With the advent of foreign policy discourse from the heart of the Revolution, this fear and insecurity feeling of revolutionary Iranians toward America-West was transferred to verbal order and discursive deed of revolutionaries self-consciously or unconsciously. "America-West" as a "horror object" lay in the central core of Islamic discourse and consequently in the central core of foreign policy discourse. In fact the horror object with security evidence ties in the central core of the Islamic Republic's foreign policy discourse and makes sense for security evidence. Peripheral components and ideology of Iran necessitate that anti-westism considers as actual norms of the Islamic Republic. Various political groups had tendencies of anti-westism which were found in the country's political scene after the Revolution.

\subsection{Task commitment}

During the Revolution, new interpretation of Imam Hussein's movement was presented. Different Iranian groups attempted to present new political allegory from justice-oriented. From their point of view, on the one hand Imam Hussein's movement has emotional and martyred nature and it is based on Judgment Day; on the other hand it is in the distinct realm of good and evil. It led to plan overall targets in Iran's foreign policy. Iran has such a political orientation that adjusts its strategic objectives beyond the structural features. Thus Iranians organize their political, social, cultural, economic and international behavior according to their religious instructions. Imam Khomeini once stated: "In the human life there is not even one issue without an Islamic instruction and solution beforehand." (Mosalinejad, 2007: 241)

\subsection{Norm making of the Great Satan and confrontation with America}

According to the ideal approach of Iranian society and also to the "Great Satan" metaphor, it seems natural to continue the conflict between truth and the Devil. In the culture of Iranians' ancient era, the Satan was the representative of evil esprit and the source of darkness and Iranians called their enemies Satan. Also in the religious culture, the Satan has a special position. The Satan is a God-expelled creature whose job is to capture human's spirit and to take him toward darkness and wickedness.

Although the symbol of the Satan lay in mythological and religious patterns of Iranian culture, the issue of West as the Satan in the revolutionaries' mind has lain the 1950s onwards. In fact the fear of giants, demons and devils and the Satan in the pre-revolutionary discourse of anti-power and the association of distorted Iranians in the anti-Western discourses were represented after the Revolution in the body of America-West. Thus Iran's foreign policy in dealing with the United States has distanced from national interests and entered the realm of cosmic ideas. The idea is considered as an impacted mission of citizens and followers of ideal justice, freedom and truth.

Occupying the American Embassy by extremist students was a reflection of the struggle of legitimacy symbols of the Islamic Revolution. There have been such spirit and act in Iranian political culture during the past.

\subsection{Opposing and resisting the hegemonic system}

Domination-bondage object in the discourse of Iran's foreign policy was represented as a "domination-like awareness" form stranger (America-West). Understanding of America-West is clear as a "domination object" in the verbal order of revolutionaries and subject discourses of foreign policy. The domination-like awareness has specified Iran's foreign policy discourse in the form of opposing against dominant West.

Therefore with reference to the constitution of the Islamic Republic we find that international orientation and foreign policy of the country lie in principles of the constitution. 152-154 principles are about foreign policy. Article 152 in the constitution of Iran declares:

"Iran's foreign policy is based on negating any hegemonism and subjugation, preserving full independency and country's territorial integrity, defending rights of all Muslims, lacking of commitment in the face of domineering powers, having peaceful relations with non-combatant states. The word "domination" in the constitution refers to history of influence and interference of foreigners. Using the words "subjugation" and "preservation of full independency" are the reflection of revolutionary spirit. 


\section{Conclusion}

The main mechanism of identity impression on foreign policy of the Islamic Republic can be considered as an impact on decision-makers' mind. Identity influence is showed in two forms: a. Impact on the behavioral pattern of the Islamic Republic b. Impact of identity components of Islamic internationalism on foreign policy.

Foundation of Iranian national identity is layered and composed of three layers (Pan-Iranism, pan-Islamism emphasizing Shi'ism, modernism). In each period and according to the culture and identity of the ruling elites, specific layers of identity were emphasized. In 1330-1332 in the time of Mossadeq, nationalism was outstanding, in the time of the second Pahlavi, Iranian layer and modernism were prominent however it did not mean ignoring Islam, from view point of Pahlavi era ruling elites it was essential to rely on the principles of democracy and secularism. Thus after the victory of the Islamic Revolution, ideological and traditional discourse dominated modernist discourse. The discourse had conflict with pluralism and civil society but in contrast it focused on leadership, moral discipline, traditional values, political elitism and cultural control. There were two major trends within the discourse of ideological traditionalism: a. Charismatic and populist tendency which was prominent from 1979 to 1989 . b. Conservative tendency which was outstanding from 1989 to 1997. Therefore the discourse led to revive and refresh traditionalism as a prominent ideology in front of modern ideologies.

The dominance of the discourse led a fundamental change in the fields of economy, politic, culture and society. The situation also influenced the field of foreign policy strongly. All fluctuations in cultural, political and economic policy of the Islamic Republic are a reflection of unclear boundaries among Iranian, Islamic and modern elements in Iran's cultural identity.

After gaining victory of Revolution and fixing the Islamic Republic; the culture and identity of ruling elites emphasized on whole community. Thus Islamic components and elements of elites led "special interpretation" from religion. The interpretation influenced on orientation and political behavior of Iran's foreign policy which revealed in the form of Islamic internationalism.

Gradually the Islamic Republic of Iran turned to the moderate form of Iranian identity such as tolerance and compromise in the encountering domestic and foreign issues. In the other word we witnessed a kind of fairly reasonable behavior according to the international principles and norms due to the international socialization. However in the recent decade, the initial values of revolution were revived in the field of foreign policy. In this period, the populist and confrontation policies with the international system were focused in addition to neglecting to international institutions and norms. In short, according to 30 years experience in the Islamic Republic of Iran, orientation and behavioral way of government depends on the cultural and identifying minutes of ruling elites in each period.

\section{References}

Ahmadi Hamid. (2004). Religion and nationality in Iran, collaboration or conflict, Extracted from Iran, identity, nationality, ethnics by Ahmadi Hamid. Institute of human science research and development, Tehran.

Bashirieh Hassan. (2005). Political ideology and social identity in Iran, Extracted from Iran, identity, nationality, ethnics by Ahmadi Hamid. Institute of human science research and development, Tehran.

Bashirieh Hassan. (2003). Political barriers in Iran, fifth edition. Game No, Tehran.

Costales Manuel. (2001). The age of information: economy, society and culture (power and identity), Vol. 2, Translated by: Chavoshian Hassan, Tarhe No publication, Tehran.

Dehghani Firouzabadi Seyed Jalal. (2007). Identity and benefit in foreign policy of Islamic Republic of Iran, Extracted from National benefit of Islamic Republic of Iran, Group of authors, Center for Strategic Studies, Tehran.

Headley Jim. (2007). Identity in foreign policy Analysis, University Otego, Paper Presented, at The British International Studies, A association annual Conference University of Cambridge. [Online] Available: http:www. Bi as. As. U k 2007 headley

Hopf Ted. (1999). The Promise of Constructivism in The International Security, International Security, Micheal Barnett, Culture, Strategy and Foreign Policy Change, Israel's road to Oslo. European journal of International Relation, Vol. 5(1), P6.

Howard Peter. (2005). Constructivism and Foreign Policy? Anew Approach to Analysis. [Online] Available: http:www.Nwo8.american edu/ Howard/isan-5.doc.2005 
Karami Jahangir. (2005). Transformation in foreign policies of Russia and the issue of the West, Office of political and international studies, Ministry of Foreign Affairs, Tehran.

Kazemi Ali Asghar. (2003). Crisis of modernism and political culture in Iran today. Ghomes, Tehran.

Mojtahedzadeh Pirouz. (2006). Justification, a phenomenon of Iranian identity, political-economic information (Part II), No. 7 \& 8.

Mojtahedzadeh Pirouz. (2007). Democracy and Iranian identity. Kavir, Tehran.

Naghibzadeh Ahmad. (2003). The impact of national culture on the foreign policy of Islamic Republic of Iran. Office of political and international studies, Tehran.

Ramazani R. K. (2004). Analytical framework for studying the foreign policy of Islamic Republic of Iran. Ney, Tehran.

Ramazani R.K. (2004). Ideology and pragmatism in Iran's Foreign policy. The middle East Journal, 58:4, Proquest social science.

Samti Mohammad Mahdi. (1997). The role of terrorism in political propaganda of America against fundamentalism. The quarterly of defense policy, No. 20-21, Fall and Winter.

Sari'olqalam Mahmoud. (2005). Globalization: Iran and globalization; challenges and solutions. Center for Strategic Research, Shahid Beheshti University, Tehran.

Tajik Mohammad Reza. (2004). Foreign policy: The field of lack of decision and thought. Farang Gofteman, Tehran. 